Article

\title{
Temperature Effect on Permeate Water in Batch Electrodialysis Reversal
}

\author{
Germán Eduardo Dévora Isiordia 1,*, Alejandra Ayala Espinoza ${ }^{2}$ and Luis Alberto Lares Rangel ${ }^{3}$ \\ 1 Department of Water and Environmental Sciences, Instituto Tecnológico de Sonora, Calle 5 de Febrero 818 \\ Sur, Ciudad Obregón, Son., México. Zip code 85000 \\ 2 Chemical Engineering, Instituto Tecnológico de Sonora, Calle 5 de Febrero 818 Sur, Ciudad Obregón, Son., \\ México. Zip code 85000; ale_ayalae@hotmail.com \\ 3 Chemical Engineering, Instituto Tecnológico de Sonora, Calle 5 de Febrero 818 Sur, Ciudad Obregón, Son., \\ México. Zip code 85000; lalrguias@gmail.com \\ * Correspondence: german.devora@itson.edu.mx
}

\begin{abstract}
Currently, a large part of the wells for agricultural use located in the state of Sonora are overexploited, which generates a high degree of saline intrusion and abandonment by nearby communities. In this paper the temperature effect on the final concentration of permeate water was evaluated through voltage and intel concentration variations in a batch electrodialysis reversal process (EDR), in order to identify optimal operating conditions with emphasis on the reduction of energy consumption and cost of desalinated water. Thirty-six samples were prepared: eighteen 2,000 mg/L total dissolved solids (TDS) samples and eighteen 5,000 mg/L TDS samples; brackish well water of $639 \mathrm{mg} / \mathrm{L} \mathrm{TDS}$ and synthetic salt were mixed to obtain those concentrations. 3 different temperatures $\left(25,30,35^{\circ} \mathrm{C}\right)$ and 2 different voltages $(10$ and $20 \mathrm{~V})$ were tested for each sample. The best salt removal occurred in the $20 \mathrm{~V}$ arrays, with $18.34 \%$ higher removal for $2,000 \mathrm{mg} / \mathrm{L}$ TDS experiments and $25.05 \%$ for $5,000 \mathrm{mg} / \mathrm{L}$ experiments (average between the 25 to $35^{\circ} \mathrm{C}$ tests). Temperature positively affected EDR, especially in the experiments at $10 \mathrm{~V}$ voltage, where increasing $10^{\circ} \mathrm{C}$ increased its efficiency by $10.83 \%$ and $24.69 \%$ for 2,000 and $5,000 \mathrm{mg} / \mathrm{L} \mathrm{TDS}$, respectively. Energy consumption was lower with increasing temperature $\left(35^{\circ} \mathrm{C}\right)$, as it decreased by $1.405 \%$ and $1.613 \%$ for 2,000 and $5,000 \mathrm{mg} / \mathrm{L}$ TDS concentrations, respectively (average between 10 and $20 \mathrm{~V}$ tests), decreasing the cost per $\mathrm{m}^{3}$ of water.
\end{abstract}

Keywords: reversible electrodialysis; water scarcity; process efficiency; temperature effect; voltage

\section{Introduction}

Water is the Earth's most invaluable resource for the development of living beings due to its participation in cellular metabolism. It is also the main resource for most human activities (household, agriculture and industry). Unlike other natural resources, water is renewed by introducing approximately $505,000 \mathrm{~km}^{3}$ every year through its circulation in the hydrological cycle [1]. Despite this, 2.1 billion people in the world do not have access to drinking water as a result of overexploitation, contamination, and poor distribution [2].

Within Mexico, the state of Sonora is located in the northwestern part of the country and $90 \%$ of the region has desert or arid conditions, where temperatures above $40{ }^{\circ} \mathrm{C}$ are reached. It has an average normal precipitation of 297 and $483 \mathrm{~mm}$ in the north and south, respectively [3]; which is below the national average. In addition, the state's renewable water per capita is 2,385 m³/year/inhabitant [3], which represents a volume $9 \%$ lower than the national per capita, despite being the second largest state in Mexico.

The problems with water availability in the region's aquifers are due to overexploitation and saline intrusion, causing a high concentration of salts in their wells [4]. Brackish water from those, when used for irrigation, damages soil properties and vegetative 
development of the crop [5]. Furthermore, a study by Monreal et al. [6] detected in 30 wells of the Hermosillo Coast aquifer that seawater intrusion has persisted since the 1960s.

Given the above problems, the opportunity arises to implement water desalination systems. These are capable of reducing the total dissolved solids (TDS) of a saline or brackish water and operate from a chemical, electrical or thermal potential [7]. Desalination processes can be classified in various ways [8-10], however, thermal and membrane systems are the most commonly employed for brackish and sea water.

Within membrane systems, Electrodialysis (ED) is a technology that uses ion exchange membranes and an applied electric current to separate salts from the aqueous medium. The feed stream crosses an array of cells (its elementary unit), consisting of an anion exchange membrane (AEM) and cation exchange membrane (CEM), which selectively attract the ions in solution and generate alternating compartments where the salts are simultaneously concentrated and reduced [11] (Figure 1).

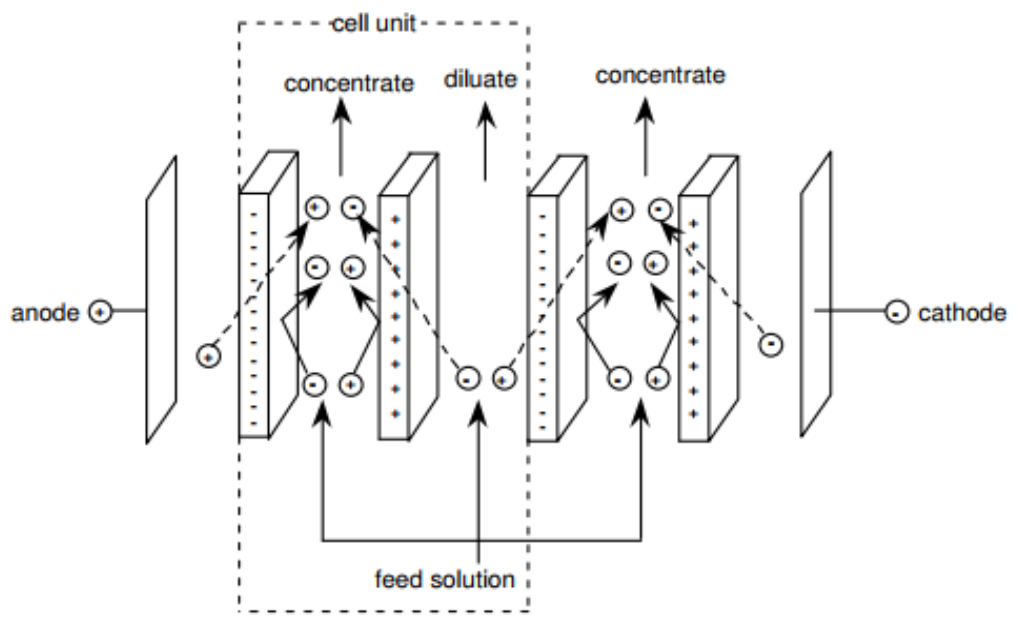

Figure 1. Diagram of the desalination principle by Electrodialysis [12].

There is a variant of the process where the polarity of the electrodes of the system is periodically inverted, which causes the concentrated and diluted compartments to change positions and, consequently, the matter that produces scaling in the membranes is redissolved and removed; this is known as Electrodialysis Reversal (EDR) [13].

Electrodialysis is mainly used in low to medium scale plants, with capacities of less than $100 \mathrm{~m}^{3} / \mathrm{d}$ to slightly more than $20,000 \mathrm{~m}^{3} / \mathrm{d}$. The success of electrodialysis is observed to a greater extent when desalinating water with total salt concentrations of less than $10,000 \mathrm{mg} / \mathrm{L}$ as in the case of wells in Sonora; however, feed sources with higher salinities close to seawater or brine are preferable to reverse osmosis. In this context, ED and EDR are attractive due of their low production cost, smaller systems that are easy to install, and the use of brackish resources from abandoned wells [11,14].

Operation in these systems is carried out on a continuous basis when large-scale and stable water production is needed, however, such installations require a large number of membranes and, therefore, suffer from large pressure drops and high energy demand; in addition, ion removal is limited [15]. In regions of Sonora where water resources are scarce, batch operation is ideal because it allows desalination of brackish water to a potable level in minutes and the production cost is lower compared to technologies such as reverse osmosis [16,17].

Transport in ion exchange membranes can be described as the combined effect of the diffusive flux generated by the concentration gradient in the boundary layer, the flux due to ion migration in the membrane, and the convective flux given the bulk velocity. The transport phenomenon can be expressed mathematically by the Nerst-Plank equation [18]:

$$
J_{i}=-D_{i} \frac{d C_{i}}{d z}-D_{i} \frac{z_{i} C_{i} F}{R T} \frac{d V}{d z}+v_{k} C_{i}
$$


Temperature plays an important role in ion transport, since the diffusivity of species $i\left(D_{i}\right)$ and ion mobility $\left(v_{i}=D_{i} / R T\right)$ are found to be a function of temperature; its effect expresses greater influence on diffusive flux in contrast to ion migration flux [19]. Another positive consequence of increasing temperature is the decrease in the electrical resistance of membranes to ion passage [20]. It is well known in the literature that for electrical power generation by reverse electrodialysis (RED) increasing the feedwater temperature results in efficiency increases $[18,19]$.

In this paper, the physicochemical parameters of the outlet stream on a batch electrodialysis reversal process in brackish water are experimentally evaluated by increasing the temperature, to define an optimal operating range for the membranes. Two concentrations, two applied voltages and three different temperatures in the feed stream were applied to construct a factorial arrangement. The imposed temperatures were selected without exceeding the limit supported by the membranes and in accordance with what a common rejection heat stream carries. The removal efficiency is expected to improve while increasing voltage and temperature, and it is desired to know to what extent this happens in a batch process. An economic evaluation of potable water production in terms of overall process energy costs was also carried out.

\section{Materials and Methods}

\subsection{Study area}

The experiment and brackish water collection were conducted at $28^{\circ} 36^{\prime} 0^{\prime \prime}$ North, $111^{\circ} 31^{\prime} 1^{\prime \prime}$ West in Ciudad Obregón, Sonora, Mexico, at the Marine Water Desalination Research Laboratory, using renewable energies (Figure 2).

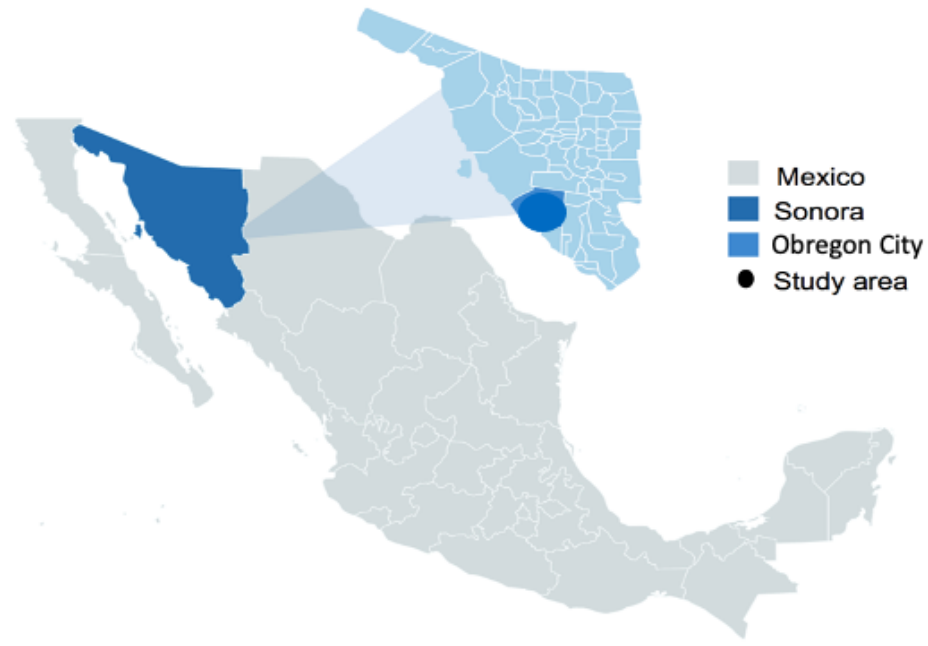

Figure 2. Area of study in Obregon City, Mexico [8].

\subsection{Preparation and characterization of feed water}

The concentration of the well water $(639 \mathrm{mg} / \mathrm{L}$ of TDS) was measured with a multiparametric equipment model YSI 556 and, by applying equation 2, and mixing synthetic salt and distilled water, 36 brackish water samples were prepared at different concentrations: 18 at 2,000 $\mathrm{mg} / \mathrm{L}$ TDS and 18 at 5,000 $\mathrm{mg} / \mathrm{L}$ TDS.

$$
C_{1} V_{1}+C_{2} V_{2}=C_{3} V_{3}
$$

Where:

$\mathrm{C}_{1}=\mathrm{TDS}$ distilled water concentration in $\mathrm{mg} / \mathrm{L}$;

$\mathrm{C}_{2}=$ TDS well water concentration in $\mathrm{mg} / \mathrm{L}$;

$\mathrm{C}_{3}=$ TDS concentration of feed water in $\mathrm{mg} / \mathrm{L}$;

$\mathrm{V}_{1}=$ Volume of distilled water in $\mathrm{L}$;

$\mathrm{V}_{2}=$ Volume of well water in $\mathrm{L}$; 
$\mathrm{V}_{3}=$ Volume of feed water in $\mathrm{L}$;

\subsection{Description of the electrodialysis equipment}

A 1 LPM ED-EDR system was used to perform the brackish water desalination tests. The system has 20 cationic membranes, 20 anionic membranes and 20 separators from GEIonics, three $0.1 \mathrm{HP}$ centrifugal pumps, 0.5 -inch PVC piping arrangement and 10 valves for flow circulation and sample collection, and three rotameters graduated at $20 \mathrm{~L} / \mathrm{min}$. The plates that divide the cationic and anionic membranes and the separators are made of titanium (where the voltage of the experiment is applied). A rectifier charge controller was also used for specific parameters: nominal voltage: $220 \mathrm{~V} / 110 \mathrm{~V}$, max. current: $30 \mathrm{~A}$, max. adjustable voltage: $20 \mathrm{~V}$, Model BX-Precision. The product, concentrate and hydrogen bubbling tanks are $3 \mathrm{~L}$ (Figure 3 ).

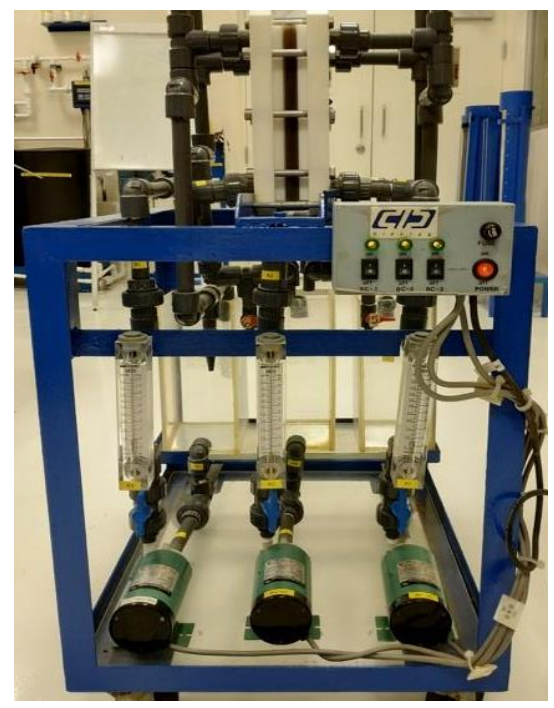

Figure 3. Front view of the electrodialysis equipment.

\subsection{System backwashing}

To guarantee the efficiency and reliability of the equipment, a backwash was performed to avoid contamination on the tests performed. The three tanks (product, concentrate and hydrogen bubbling) are washed with tap water; after draining the liquid, 1 liter of distilled water is added to each tank and the electrodialysis equipment is connected to $110 \mathrm{~V}$ electric current. It is always necessary to check the valve arrangement, keeping valves 1, 2 and 3 open and 4-10 closed (see Figure 4). Subsequently, the circulation pumps are turned on for 1 minute to homogenize and finally drain the water. 


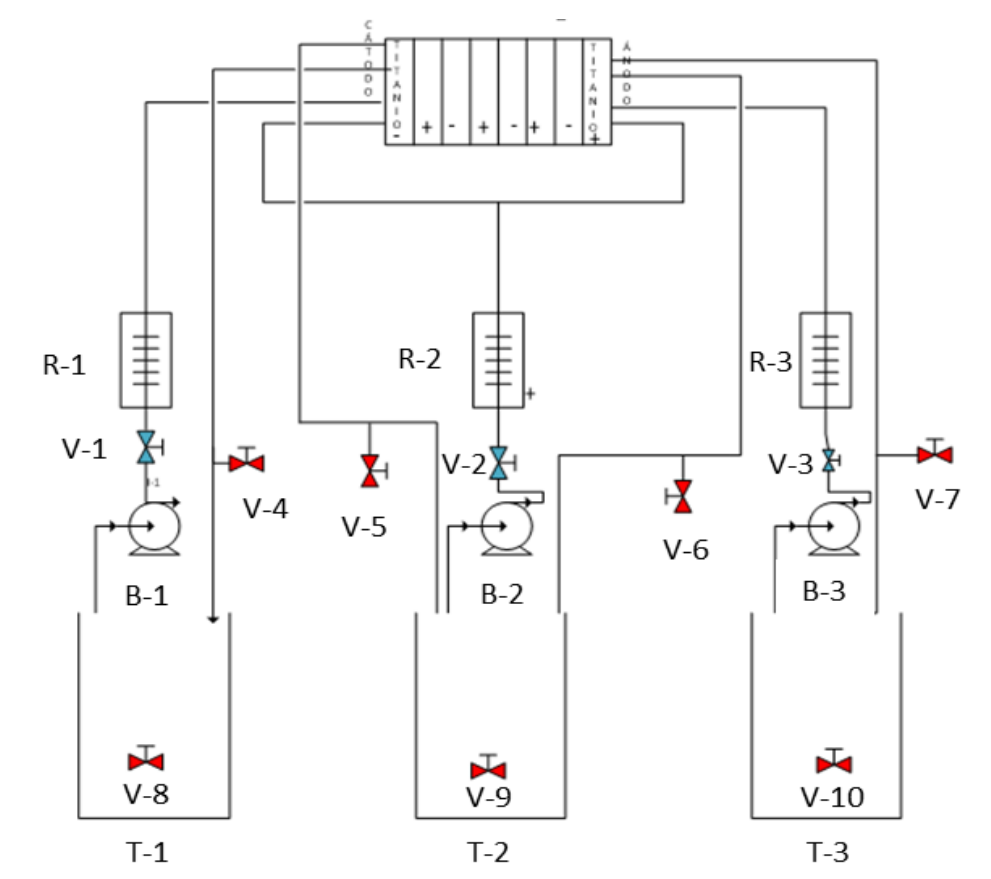

Figure 4. Piping diagram in the electrodialysis equipment.

T-1: Product tank;

T-2: Hydrogen bubbling tank;

T-3: Concentrate tank;

B-1, B-2 and B-3: Centrifugal pump;

R-1, R-2 and R-3: Rotameter;

V-1, V-2, V-3, V-4, V-5, V-6, V-7, V-8, V-9, V-10: Shut-off valves;

\subsection{Set-up of EDR experiments}

A 3-factor factorial arrangement was designed for 12 different tests in triplicate. For this, three temperatures $\left(25,30,35^{\circ} \mathrm{C}\right)$, two voltages $(10$ and $20 \mathrm{~V})$ and two different concentrations (2000 and $5000 \mathrm{mg} / \mathrm{L}$ ) were used. The arrangements can be seen in

Figure 5.

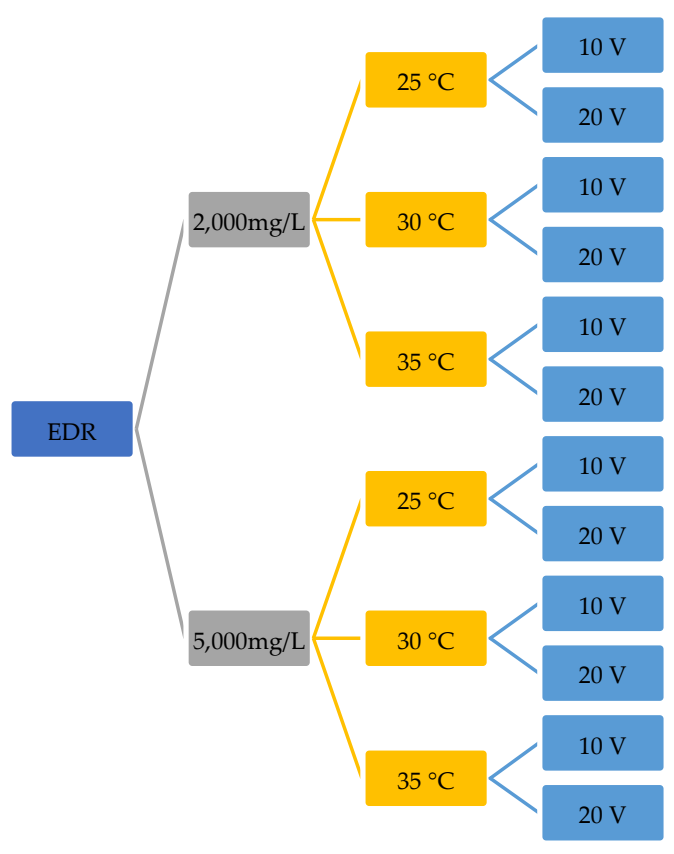


Figure 5. Temperature-voltage-concentration arrangements.

\subsection{Operation of EDR equipment}

$9 \mathrm{~L}$ of water were heated from an electric resistance (water heater) and homogenized with propeller agitator; they were poured in the same proportion into the three tanks ( $3 \mathrm{~L}$ per tank). Subsequently, the three pumps were turned on to prepare the equipment, and the voltage was adjusted using a BK Precision 1672 rectifier. Six samples were collected from the concentrate tank and six from the product tank at different times throughout the experiment, as shown in Table 1. In order to maintain consistency with the measurement of the other tests, the experiment ended at 19 minutes.

Table 1. Sample collection interval.

\begin{tabular}{cc}
\hline Sample & Time (min) \\
\hline 1 & 4 \\
2 & 7 \\
3 & 10 \\
4 & 13 \\
5 & 16 \\
6 & 19 \\
\hline
\end{tabular}

\subsection{Process control parameters}

Also, a wattmeter was used to record the energy consumed by the pump system and the rectifier during each experiment.

The parameters used to control and monitor the evolution of the process were removal efficiency (\%) and conversion (\%) [21]. The removal efficiency of the experiments was estimated by the ratio of the salts removed to the salts initially contained:

$$
\text { Removal Efficiency }=\frac{\mathrm{SDT}_{\text {initial }}-\mathrm{SDT}_{\text {final }}}{\mathrm{SDT}_{\text {initial }}} \times 100
$$

Where:

SDTinitial: Concentration of salts in feed water $(\mathrm{mg} / \mathrm{L})$;

$\mathrm{SDT}_{\text {final: }}$ Concentration of the product tank at the end of the experiment $(\mathrm{mg} / \mathrm{L})$;

The conversion (recovery) percentage is the volume of water that is obtained as product or the percentage of water recovered; it is obtained through the following equation:

$$
\text { Recovery }=\frac{Q_{p}}{Q_{a}} \times 100=\frac{Q_{p}}{Q_{r}+Q_{p}} \times 100
$$

Where:

$\mathrm{Q}_{\mathrm{p}}$ : Permeate flow rate $(\mathrm{L} / \mathrm{min})$;

$\mathrm{Q}_{\mathrm{a}}$ : Feed flow rate (L/min);

Qr: Rejection flow rate $(\mathrm{L} / \mathrm{min})$;

The typical recovery used in electrodialysis is around 85-90\% [22], however, in all experiments a water conversion of $50 \%$ was maintained to avoid overloading the pumping system beyond its capacity.

\section{Results and Discussion}

\subsection{Characteristics of the water sample}

The characteristics of the well water sample are shown in

Table 2 and from this the feed water, from which the laboratory tests were performed, was created. 
Table 2. Caractheristics of well water.

\begin{tabular}{cc}
\hline Parameters & Value \\
\hline Volume (L) & 300 \\
TDS $(\mathrm{mg} / \mathrm{L})$ & 639 \\
$\mathrm{pH}$ & 8.1 \\
Conductivity $(\mathrm{mS} / \mathrm{cm})$ & 0.9922 \\
Temperature $\left({ }^{\circ} \mathrm{C}\right)$ & $19.91 \pm 1.3$ \\
\hline
\end{tabular}

\subsection{Applied voltage effect (10 and $20 \mathrm{~V}$ )}

The results of the 12 tests are shown in Table 3 through Table 8 . The trend of all experiments is an increase in the electrical conductivity in the reject water and a decrease in total dissolved solids in the product water.

Table 3. Desalination results for the $2,000 \mathrm{mg} / \mathrm{L}$ TDS sample at $25^{\circ} \mathrm{C}$.

\begin{tabular}{|c|c|c|c|c|c|c|c|c|}
\hline \multirow{3}{*}{$\begin{array}{l}\text { Time } \\
\text { (min) }\end{array}$} & \multicolumn{4}{|c|}{$10 \mathrm{~V}$} & \multicolumn{4}{|c|}{$20 \mathrm{~V}$} \\
\hline & \multicolumn{2}{|c|}{ Product Water } & \multicolumn{2}{|c|}{ Concentrate Water } & \multicolumn{2}{|c|}{ Product Water } & \multicolumn{2}{|c|}{ Concentrate Water } \\
\hline & $\begin{array}{c}\mathrm{EC} \\
(\mu \mathrm{S} / \mathrm{cm})\end{array}$ & $\begin{array}{c}\text { TDS } \\
(\mathrm{mg} / \mathrm{L})\end{array}$ & $\begin{array}{c}\mathrm{EC} \\
(\mu \mathrm{S} / \mathrm{cm})\end{array}$ & $\begin{array}{c}\text { TDS } \\
(\mathrm{mg} / \mathrm{L})\end{array}$ & $\begin{array}{c}\mathrm{EC} \\
(\mu \mathrm{S} / \mathrm{cm})\end{array}$ & $\begin{array}{c}\text { TDS } \\
\text { (mg/L) }\end{array}$ & $\begin{array}{c}\mathrm{EC} \\
(\mu \mathrm{S} / \mathrm{cm})\end{array}$ & $\begin{array}{c}\text { TDS } \\
(\mathrm{mg} / \mathrm{L})\end{array}$ \\
\hline 0 & 3.14 & 2020.55 & 3.14 & 2020.55 & 3.15 & 2031.50 & 3.15 & 2028.60 \\
\hline 4 & 2.63 & 1695.33 & 3.31 & 2128.42 & 2.03 & 1309.25 & 3.77 & 2426.16 \\
\hline 7 & 2.30 & 1477.98 & 3.73 & 2404.37 & 1.51 & 974.37 & 4.41 & 2842.62 \\
\hline 10 & 1.92 & 1234.87 & 3.96 & 2548.31 & 0.95 & 613.09 & 4.76 & 3066.94 \\
\hline 13 & 1.51 & 970.19 & 4.31 & 2775.96 & 0.57 & 367.72 & 5.12 & 3298.57 \\
\hline 16 & 1.18 & 757.67 & 4.78 & 3080.90 & 0.39 & 285.94 & 5.32 & 3426.72 \\
\hline 19 & 0.92 & 589.26 & 5.15 & 3319.18 & 0.22 & 142.97 & 5.50 & 3541.36 \\
\hline
\end{tabular}

Table 4. Desalination results for the $2,000 \mathrm{mg} / \mathrm{L}$ TDS sample at $30^{\circ} \mathrm{C}$.

\begin{tabular}{|c|c|c|c|c|c|c|c|c|}
\hline \multirow{3}{*}{$\begin{array}{l}\text { Time } \\
\text { (min) }\end{array}$} & \multicolumn{4}{|c|}{$10 \mathrm{~V}$} & \multicolumn{4}{|c|}{$20 \mathrm{~V}$} \\
\hline & \multicolumn{2}{|c|}{ Product Water } & \multicolumn{2}{|c|}{ Concentrate Water } & \multicolumn{2}{|c|}{ Product Water } & \multicolumn{2}{|c|}{ Concentrate Water } \\
\hline & $\begin{array}{c}\text { EC } \\
(\mu S / \mathrm{cm})\end{array}$ & $\begin{array}{c}\text { TDS } \\
(\mathrm{mg} / \mathrm{L})\end{array}$ & $\begin{array}{c}\text { EC } \\
(\mu S / \mathrm{cm})\end{array}$ & $\begin{array}{c}\text { TDS } \\
(\mathrm{mg} / \mathrm{L})\end{array}$ & $\begin{array}{c}\text { EC } \\
(\mu S / \mathrm{cm})\end{array}$ & $\begin{array}{c}\text { TDS } \\
(\mathrm{mg} / \mathrm{L})\end{array}$ & $\begin{array}{c}\text { EC } \\
(\mu S / \mathrm{cm})\end{array}$ & $\begin{array}{c}\text { TDS } \\
(\mathrm{mg} / \mathrm{L})\end{array}$ \\
\hline 0 & 3.12 & 2009.28 & 3.12 & 2009.28 & 3.12 & 2010.25 & 3.11 & 2005.85 \\
\hline 4 & 2.45 & 1575.87 & 3.29 & 2115.54 & 2.14 & 1374.94 & 3.58 & 2303.37 \\
\hline 7 & 2.05 & 1317.62 & 3.65 & 2351.89 & 1.63 & 1046.50 & 4.32 & 2780.58 \\
\hline 10 & 1.79 & 1150.51 & 4.06 & 2612.06 & 0.83 & 592.48 & 4.77 & 3071.45 \\
\hline 13 & 1.53 & 878.09 & 4.35 & 2799.79 & 0.57 & 366.01 & 5.02 & 3232.45 \\
\hline 16 & 1.04 & 667.83 & 4.59 & 2955.64 & 0.40 & 257.92 & 5.39 & 3469.44 \\
\hline 19 & 0.85 & 545.15 & 4.77 & 3070.27 & 0.21 & 136.85 & 5.53 & 3564.11 \\
\hline
\end{tabular}

Table 5. Desalination results for the $2,000 \mathrm{mg} / \mathrm{L}$ TDS sample at $35^{\circ} \mathrm{C}$.

\begin{tabular}{|c|c|c|c|c|c|c|c|c|}
\hline \multirow{3}{*}{$\begin{array}{l}\text { Time } \\
\text { (min) }\end{array}$} & \multicolumn{4}{|c|}{$10 \mathrm{~V}$} & \multicolumn{4}{|c|}{$20 \mathrm{~V}$} \\
\hline & \multicolumn{2}{|c|}{ Product Water } & \multicolumn{2}{|c|}{ Concentrate Water } & \multicolumn{2}{|c|}{ Product Water } & \multicolumn{2}{|c|}{ Concentrate Water } \\
\hline & $\begin{array}{c}\mathrm{EC} \\
(\mu \mathrm{S} / \mathrm{cm})\end{array}$ & $\begin{array}{c}\text { TDS } \\
(\mathrm{mg} / \mathrm{L})\end{array}$ & $\begin{array}{c}\mathrm{EC} \\
(\mu \mathrm{S} / \mathrm{cm})\end{array}$ & $\begin{array}{c}\text { TDS } \\
(\mathrm{mg} / \mathrm{L})\end{array}$ & $\begin{array}{c}\mathrm{EC} \\
(\mu \mathrm{S} / \mathrm{cm})\end{array}$ & $\begin{array}{c}\text { TDS } \\
(\mathrm{mg} / \mathrm{L})\end{array}$ & $\begin{array}{c}\mathrm{EC} \\
(\mu \mathrm{S} / \mathrm{cm})\end{array}$ & $\begin{array}{c}\text { TDS } \\
(\mathrm{mg} / \mathrm{L})\end{array}$ \\
\hline 0 & 3.11 & 1999.62 & 3.11 & 1999.62 & 3.14 & 2023.13 & 3.14 & 2021.73 \\
\hline 4 & 2.13 & 1374.62 & 3.48 & 2242.09 & 1.84 & 1181.74 & 3.66 & 2356.40 \\
\hline 7 & 1.73 & 1115.73 & 3.96 & 2548.63 & 1.40 & 902.24 & 4.29 & 2763.40 \\
\hline 10 & 1.35 & 869.40 & 4.27 & 2752.78 & 0.89 & 570.58 & 4.76 & 3066.94 \\
\hline 13 & 0.88 & 565.75 & 4.59 & 2954.99 & 0.56 & 360.64 & 5.04 & 3244.90 \\
\hline 16 & 0.68 & 435.67 & 4.82 & 3103.44 & 0.31 & 200.28 & 5.28 & 3398.39 \\
\hline
\end{tabular}




\begin{tabular}{|c|c|c|c|c|c|c|c|c|}
\hline 19 & 0.57 & 366.44 & 5.06 & 3257.67 & 0.18 & 116.56 & 5.39 & 3468.37 \\
\hline \multirow{3}{*}{$\begin{array}{l}\text { Time } \\
\text { (min) }\end{array}$} & \multicolumn{4}{|c|}{$10 \mathrm{~V}$} & \multicolumn{4}{|c|}{$20 \mathrm{~V}$} \\
\hline & \multicolumn{2}{|c|}{ Product Water } & \multicolumn{2}{|c|}{ Concentrate Water } & \multicolumn{2}{|c|}{ Product Water } & \multicolumn{2}{|c|}{ Concentrate Water } \\
\hline & $\begin{array}{c}\mathrm{EC} \\
(\mu \mathrm{S} / \mathrm{cm})\end{array}$ & $\begin{array}{c}\text { TDS } \\
(\mathrm{mg} / \mathrm{L})\end{array}$ & $\begin{array}{c}\mathrm{EC} \\
(\mu \mathrm{S} / \mathrm{cm})\end{array}$ & $\begin{array}{c}\text { TDS } \\
(\mathrm{mg} / \mathrm{L})\end{array}$ & $\begin{array}{c}\mathrm{EC} \\
(\mu \mathrm{S} / \mathrm{cm})\end{array}$ & $\begin{array}{c}\text { TDS } \\
\text { (mg/L) }\end{array}$ & $\begin{array}{c}\mathrm{EC} \\
(\mu \mathrm{S} / \mathrm{cm})\end{array}$ & $\begin{array}{c}\text { TDS } \\
(\mathrm{mg} / \mathrm{L})\end{array}$ \\
\hline 0 & 7.86 & 5064.63 & 7.86 & 5064.63 & 7.79 & 5015.15 & 7.79 & 5015.15 \\
\hline 4 & 6.83 & 4397.45 & 7.93 & 5104.56 & 5.74 & 3697.20 & 8.24 & 5307.53 \\
\hline 7 & 6.22 & 4008.69 & 8.48 & 5462.19 & 4.95 & 3185.22 & 9.56 & 6157.61 \\
\hline 10 & 5.65 & 3641.18 & 8.94 & 5756.29 & 3.75 & 2415.64 & 10.53 & 6781.32 \\
\hline 13 & 4.86 & 3126.83 & 9.46 & 6091.17 & 2.78 & 1788.39 & 11.41 & 7344.82 \\
\hline 16 & 4.25 & 2738.29 & 9.86 & 6351.56 & 2.05 & 1319.23 & 12.10 & 7792.40 \\
\hline 19 & 3.75 & 2414.14 & 10.33 & 6651.45 & 0.97 & 623.39 & 12.78 & 8230.32 \\
\hline
\end{tabular}

Table 7. Desalination results for the 5,000 mg/L TDS sample at $30^{\circ} \mathrm{C}$.

\begin{tabular}{|c|c|c|c|c|c|c|c|c|}
\hline \multirow{3}{*}{$\begin{array}{l}\text { Time } \\
\text { (min) }\end{array}$} & \multicolumn{4}{|c|}{$10 \mathrm{~V}$} & \multicolumn{4}{|c|}{$20 \mathrm{~V}$} \\
\hline & \multicolumn{2}{|c|}{ Product Water } & \multicolumn{2}{|c|}{ Concentrate Water } & \multicolumn{2}{|c|}{ Product Water } & \multicolumn{2}{|c|}{ Concentrate Water } \\
\hline & $\begin{array}{c}\text { EC } \\
(\mu S / \mathrm{cm})\end{array}$ & $\begin{array}{c}\text { TDS } \\
(\mathrm{mg} / \mathrm{L})\end{array}$ & $\begin{array}{c}\text { EC } \\
(\mu \mathrm{S} / \mathrm{cm})\end{array}$ & $\begin{array}{c}\text { TDS } \\
(\mathrm{mg} / \mathrm{L})\end{array}$ & $\begin{array}{c}\mathrm{EC} \\
(\mu \mathrm{S} / \mathrm{cm})\end{array}$ & $\begin{array}{c}\text { TDS } \\
(\mathrm{mg} / \mathrm{L})\end{array}$ & $\begin{array}{c}\text { EC } \\
(\mu S / \mathrm{cm})\end{array}$ & $\begin{array}{c}\text { TDS } \\
(\mathrm{mg} / \mathrm{L})\end{array}$ \\
\hline 0 & 7.82 & 5038.44 & 7.82 & 5038.44 & 7.70 & 4958.16 & 7.69 & 4954.72 \\
\hline 4 & 6.33 & 4073.51 & 8.39 & 5401.87 & 5.00 & 3218.39 & 8.84 & 5693.39 \\
\hline 7 & 5.80 & 3733.05 & 9.16 & 5897.97 & 3.93 & 2528.99 & 10.33 & 6654.67 \\
\hline 10 & 4.92 & 3168.05 & 9.90 & 6374.53 & 2.79 & 1799.66 & 11.38 & 7326.57 \\
\hline 13 & 4.19 & 2700.51 & 10.61 & 6832.84 & 1.93 & 1241.63 & 12.25 & 7889.00 \\
\hline 16 & 3.48 & 2240.48 & 11.15 & 7182.75 & 1.25 & 807.90 & 12.69 & 8174.51 \\
\hline 19 & 2.93 & 1889.07 & 11.60 & 7468.25 & 0.81 & 520.35 & 13.14 & 8464.31 \\
\hline
\end{tabular}

Table 8. Desalination results for the $5,000 \mathrm{mg} / \mathrm{L}$ TDS sample at $35^{\circ} \mathrm{C}$.

\begin{tabular}{|c|c|c|c|c|c|c|c|c|}
\hline \multirow{3}{*}{$\begin{array}{l}\text { Time } \\
\text { (min) }\end{array}$} & \multicolumn{4}{|c|}{$10 \mathrm{~V}$} & \multicolumn{4}{|c|}{$20 \mathrm{~V}$} \\
\hline & \multicolumn{2}{|c|}{ Product Water } & \multicolumn{2}{|c|}{ Concentrate Water } & \multicolumn{2}{|c|}{ Product Water } & \multicolumn{2}{|c|}{ Concentrate Water } \\
\hline & $\begin{array}{c}\text { EC } \\
(\mu S / \mathrm{cm})\end{array}$ & $\begin{array}{c}\text { TDS } \\
(\mathrm{mg} / \mathrm{L})\end{array}$ & $\begin{array}{c}\mathrm{EC} \\
(\mu \mathrm{S} / \mathrm{cm})\end{array}$ & $\begin{array}{c}\text { TDS } \\
(\mathrm{mg} / \mathrm{L})\end{array}$ & $\begin{array}{c}\mathrm{EC} \\
(\mu \mathrm{S} / \mathrm{cm})\end{array}$ & $\begin{array}{c}\text { TDS } \\
(\mathrm{mg} / \mathrm{L})\end{array}$ & $\begin{array}{c}\mathrm{EC} \\
(\mu \mathrm{S} / \mathrm{cm})\end{array}$ & $\begin{array}{c}\text { TDS } \\
(\mathrm{mg} / \mathrm{L})\end{array}$ \\
\hline 0 & 7.81 & 5027.71 & 7.81 & 5029.00 & 7.80 & 5021.27 & 7.79 & 5015.90 \\
\hline 4 & 6.28 & 4046.47 & 8.31 & 5348.42 & 4.92 & 3167.84 & 9.04 & 5823.48 \\
\hline 7 & 5.36 & 3454.20 & 9.45 & 6087.95 & 3.16 & 2034.07 & 10.32 & 6643.50 \\
\hline 10 & 4.33 & 2785.51 & 10.51 & 6766.29 & 2.29 & 1472.18 & 11.61 & 7474.69 \\
\hline 13 & 3.39 & 2181.01 & 11.06 & 7124.79 & 1.62 & 1045.21 & 12.33 & 7938.37 \\
\hline 16 & 2.65 & 1709.18 & 11.83 & 7616.59 & 1.14 & 733.19 & 12.93 & 8326.92 \\
\hline 19 & 1.79 & 1155.55 & 12.42 & 7998.48 & 0.79 & 506.18 & 13.50 & 8696.15 \\
\hline
\end{tabular}


The behavior of the product $(\mathrm{P})$ and rejection (or concentrate) (R) streams of each experiment are shown in Figure 6 and Figure 7 as a function of time, comparing both applied voltages.

$25^{\circ} \mathrm{C}$

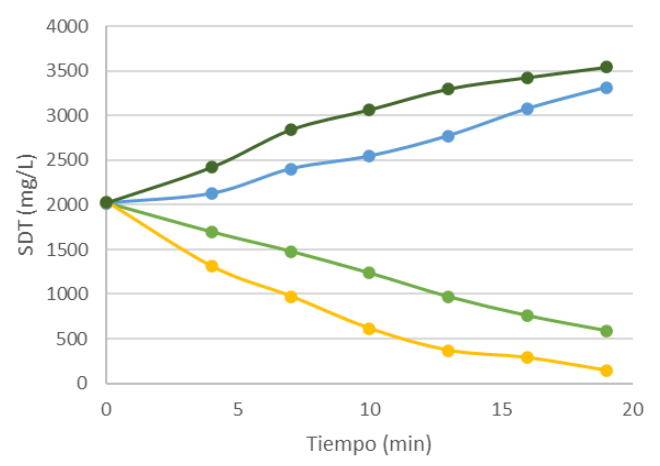

$25^{\circ} \mathrm{C}$

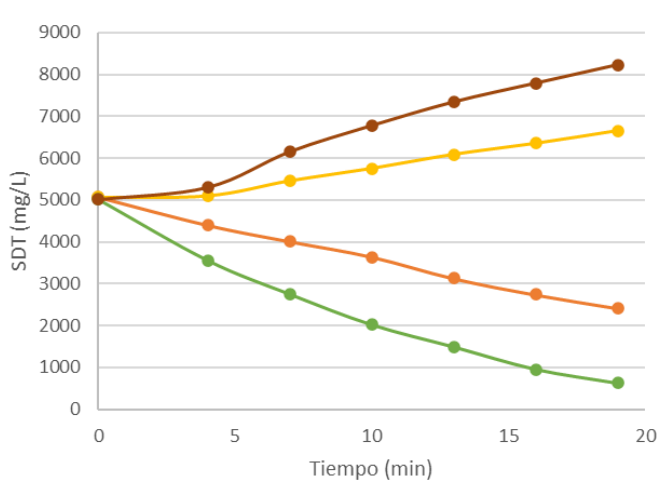

$30{ }^{\circ} \mathrm{C}$

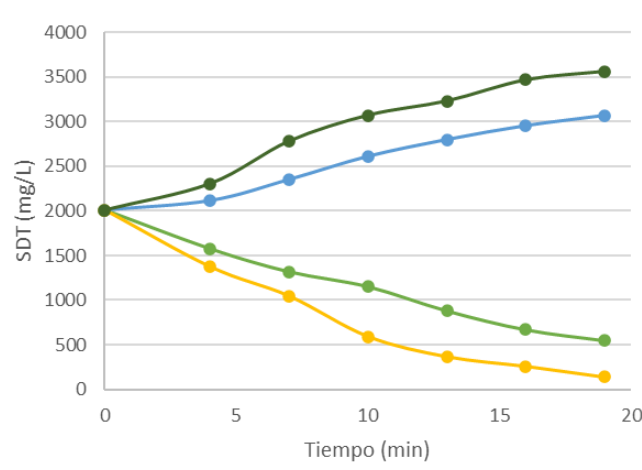

$35^{\circ} \mathrm{C}$

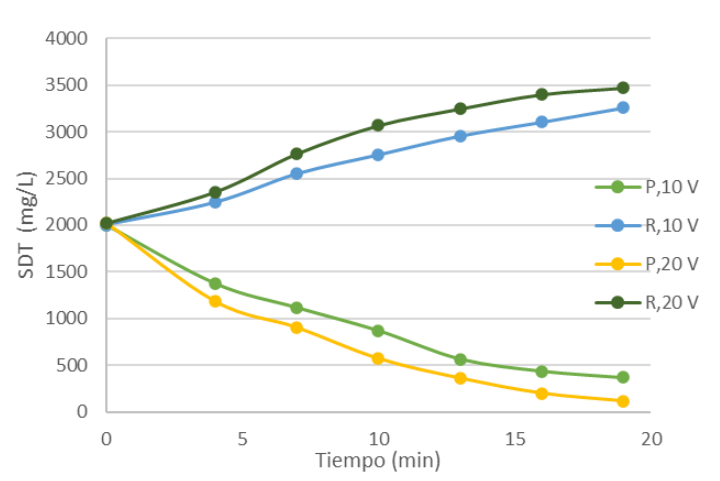

Figure 6. TDS evolution in tests at 2,000 $\mathrm{mg} / \mathrm{L}$.

$30^{\circ} \mathrm{C}$

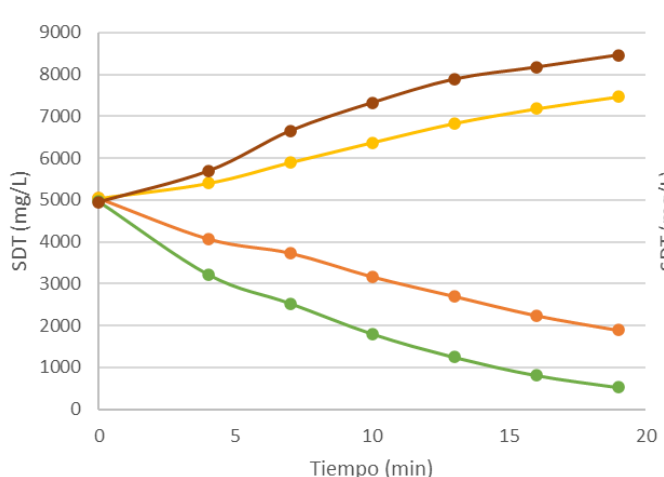

$35^{\circ} \mathrm{C}$

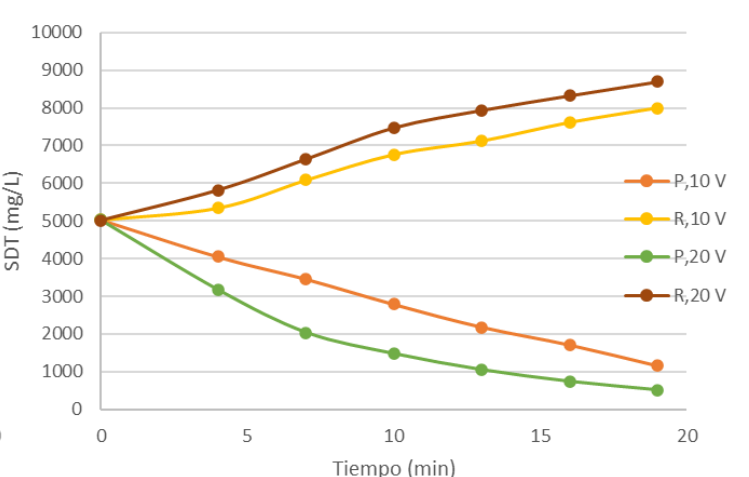

Figure 7. TDS evolution in tests at 5,000 mg/L. 
In the first four minutes the most abrupt decrease is identified and, as described in equation 1, the experiments in which a voltage of $20 \mathrm{~V}$ was applied, achieved a higher removal of TDS because the transport of ions in the membranes increases with voltage. The comparative analysis of each case can be seen in Table 9 . For case $1(2,000 \mathrm{mg} / \mathrm{L}$ TDS at $25^{\circ} \mathrm{C}$ ), there was a difference of $22.13 \%$ between 10 and $20 \mathrm{~V}$ tests, with removal values of $70.84 \%$ and $92.96 \%$, respectively. The average difference in the $2,000 \mathrm{mg} / \mathrm{L}$ TDS process was $18.34 \%$ and that of $5,000 \mathrm{mg} / \mathrm{L}$ was $25.05 \%$, with the $20 \mathrm{~V}$ tests being more efficient.

Table 9. Difference in efficiency of experiments at 10 and $20 \mathrm{~V}$.

\begin{tabular}{ccccc}
\hline Case & Arrangement & $\begin{array}{c}\text { Efficiency (\%) } \\
\mathbf{1 0 ~ V}\end{array}$ & $\begin{array}{c}\text { Efficiency (\%) } \\
\mathbf{2 0 ~ V}\end{array}$ & $\begin{array}{c}\text { Difference } \\
\mathbf{( \% )}\end{array}$ \\
\hline 1 & $2,000 \mathrm{SDT}-25^{\circ} \mathrm{C}$ & $70.84 \pm 7.35$ & $92.96 \pm 2.38$ & 22.13 \\
2 & $2,000 \mathrm{SDT}-30^{\circ} \mathrm{C}$ & $72.87 \pm 13.45$ & $93.19 \pm 3.68$ & 20.32 \\
3 & $2,000 \mathrm{SDT}-35^{\circ} \mathrm{C}$ & $81.67 \pm 10.88$ & $94.24 \pm 0.11$ & 12.56 \\
4 & $5,000 \mathrm{SDT}-25^{\circ} \mathrm{C}$ & $52.33 \pm 18.25$ & $87.57 \pm 1.33$ & 35.24 \\
5 & $5,000 \mathrm{SDT}-30^{\circ} \mathrm{C}$ & $62.51 \pm 14.95$ & $89.5 \pm 10.25$ & 27 \\
6 & $5,000 \mathrm{SDT}-35^{\circ} \mathrm{C}$ & $77.02 \pm 10.62$ & $89.92 \pm 4.28$ & 12.9 \\
\hline
\end{tabular}

\subsection{Evaluation of the effect of temperature on removal efficiency}

The following section discusses the impact of feed water temperature on process efficiency. This is done for the two applied voltages (10 and $20 \mathrm{~V})$ and the two inlet concentrations $(2,000$ and $5,000 \mathrm{mg} / \mathrm{L})$; also, the differences between the two kinds of tests are analyzed.

\subsubsection{Effect of temperature on the experiments at $10 \mathrm{~V}$}

In all tests, no difference was detected in the temperature of the diluate streams compared to the concentrate streams at every sample taking. The resulting efficiencies in the tests at 5,000 mg/L and 2,000 mg/L at different temperatures are compiled in Figure 8.

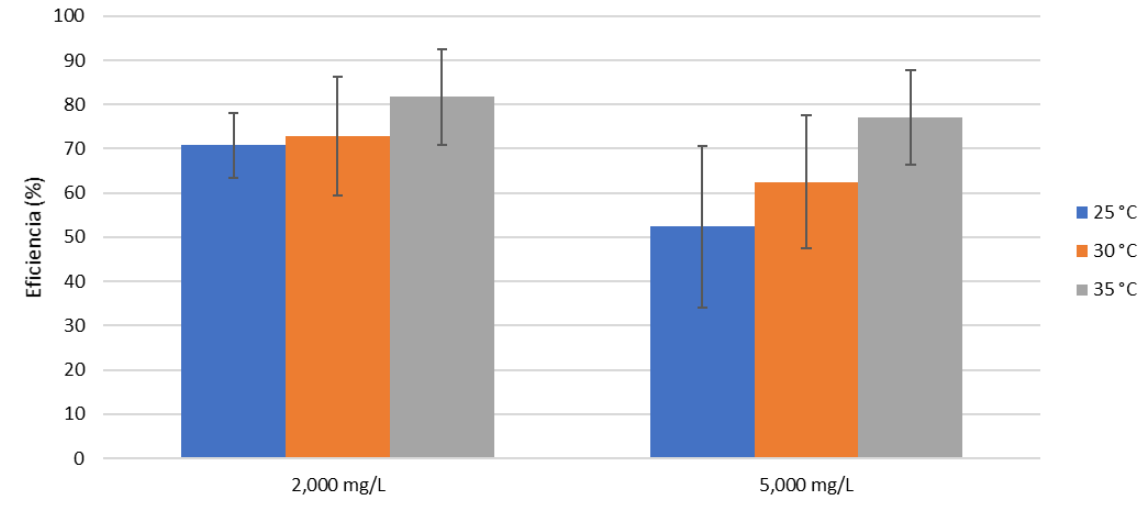

Figure 8. Effect of inlet temperature on removal efficiency in experiments at $10 \mathrm{~V}$.

Both solutions show an increase in salt removal efficiency as the feed water temperature increases. There was an improvement of $10.83 \%$ and $24.69 \%$ as the temperature was increased by $10{ }^{\circ} \mathrm{C}$ in the 2,000 mg/L and 5,000 mg/L solutions, respectively. Other studies $[19,23]$, in which a similar method is replicated, state that the increase in diffusivity and ion mobility with increasing temperature is the factor that defines the behavior of the removal efficiency in the process. It is also possible to highlight that the increase in salt removal between the $25-35^{\circ} \mathrm{C}$ tests of the $2,000 \mathrm{mg} / \mathrm{L}$ samples was less noticeable compared to the $5,000 \mathrm{mg} / \mathrm{L}$ samples. This can be attributed to the non-stationary nature of the process due to the batch operation; that is, for the operation time of the experiment, and because of the lower salt content, the final portion of the curve is reached faster when working with the 2,000 $\mathrm{mg} / \mathrm{L}$ sample [24]. 


\subsubsection{Effect of temperature on the experiments at $20 \mathrm{~V}$}

The trend in removal efficiency is similar to the experiments in the previous section, however, the growth in salt separation while increasing temperature is less pronounced; around $1 \%$ for both feed concentrations (Figure 9). Also, the applied voltage is sufficient to remove salts beyond $85 \%$, which implies $20 \mathrm{~V}$ as a voltage that allows high efficiencies to be achieved without much sensitivity to temperature in the ranges operated.

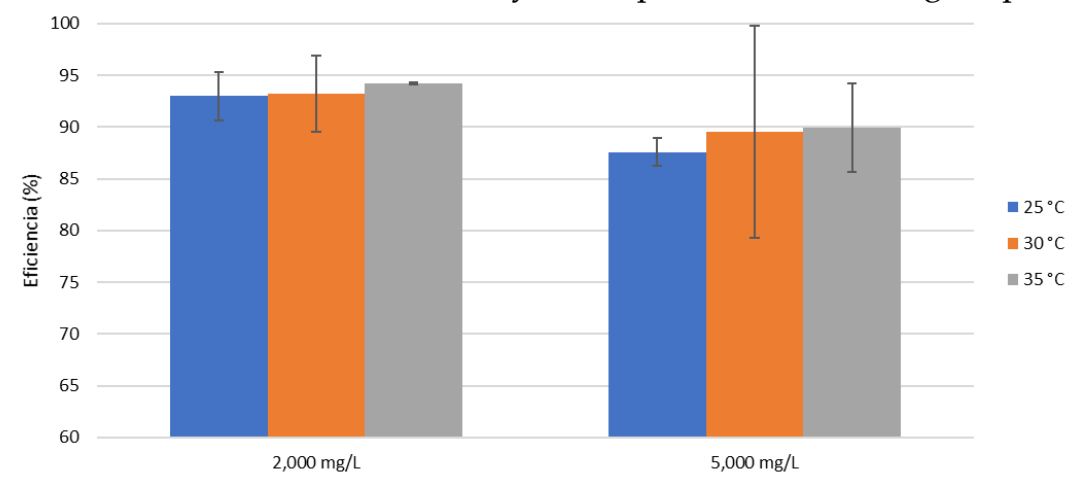

Figure 9. Effect of inlet temperature on removal efficiency in experiments at $20 \mathrm{~V}$.

\subsubsection{Evaluation of product water over time}

Another important point of comparison is the salinity of the product water with respect to the Official Mexican Standard 127 [25], which indicates 1,000 mg/L TDS as a permissible limit for water for human consumption. Figure 10 and Figure 11 show how TDS is eliminated over time for the samples at the three inlet temperatures and the two voltages.

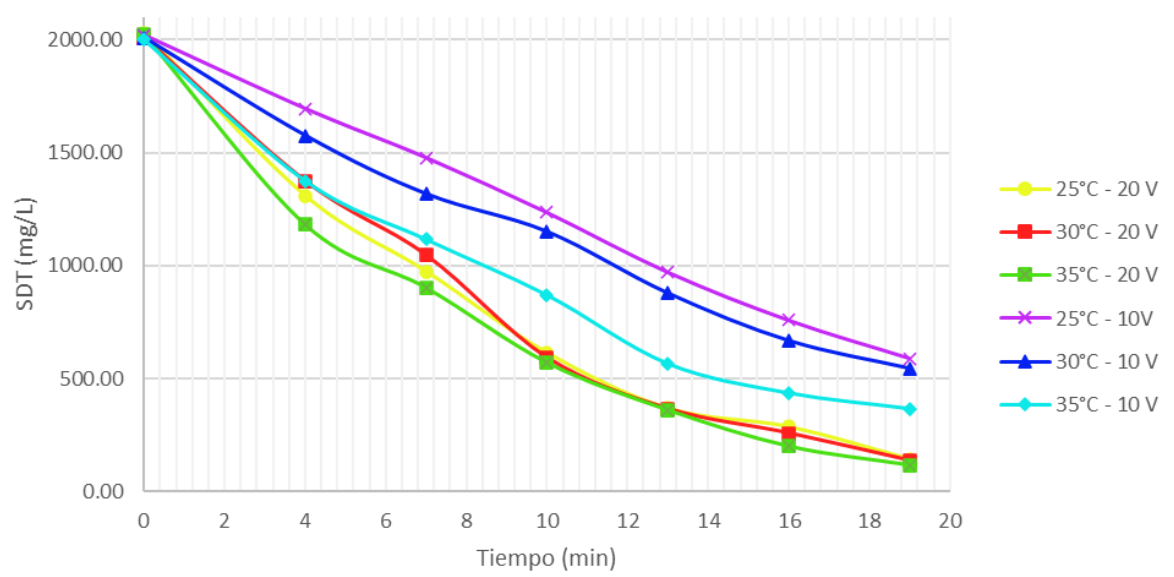

Figure 10. Desalination of the 2,000 mg/L TDS samples at the chosen temperatures and initial concentrations. 


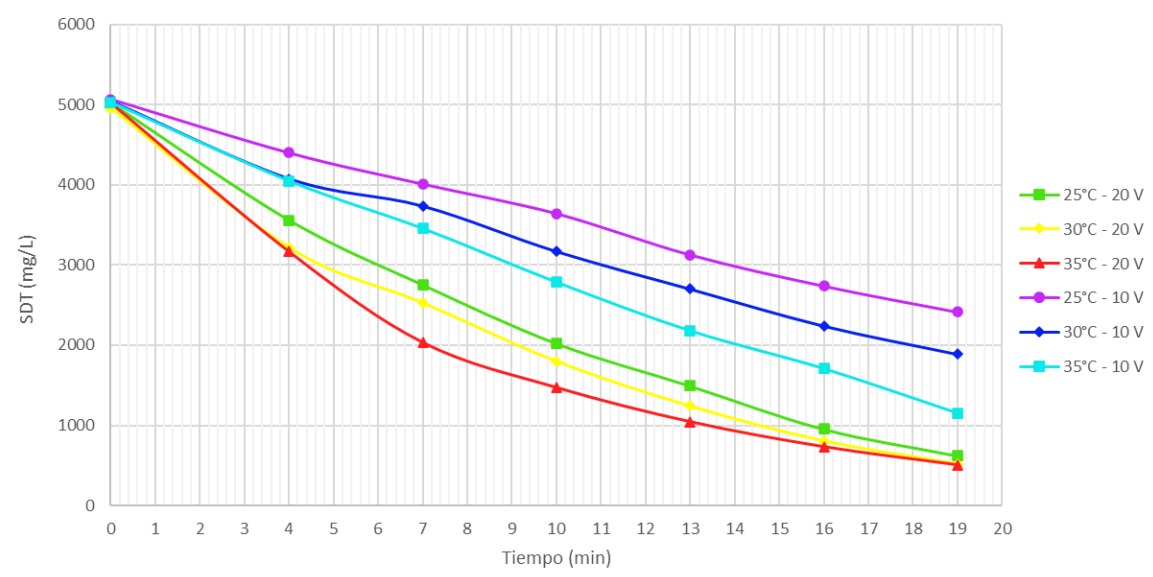

Figure 11. Desalination of the 5,000 mg/L TDS samples at the chosen temperatures and initial concentrations.

As expected, the $20 \mathrm{~V}$ tests achieved a concentration of less than 1,000 mg/L TDS of product water the fastest, with the $35{ }^{\circ} \mathrm{C}$ samples being the first to meet this parameter. With the 2,000 and 5,000 mg/L sample such removal is achieved in approximately 7.7 and 13.4 minutes, respectively. Under this perspective it is also possible to detect how the temperature does not produce too much effect when working in these voltage conditions, since the curves are almost together and the final concentration is almost the same in its final portion.

\subsubsection{Energy demand of the process}

It is relevant to know the difference in energy consumption in the different tests in order to know how profitable it is to increase the voltage and temperature of the process, so the cases were compared again to see how the energy consumption behaved. Table 10 shows the results corresponding to the energy used by the pumping equipment and the rectifier, and Table 11 shows the total consumption.

Table 10. Average pump and rectifier energy demand for each test.

\begin{tabular}{ccccc}
\hline \multirow{2}{*}{ Arrangement } & \multicolumn{2}{c}{ Pump (kWh) } & \multicolumn{2}{c}{ Rectifier (kWh) } \\
& $\mathbf{1 0 ~ V}$ & $\mathbf{2 0 ~ V}$ & $\mathbf{1 0 ~ V}$ & $\mathbf{2 0 ~ V}$ \\
\hline $2,000 \mathrm{mg} / \mathrm{L}-25^{\circ} \mathrm{C}$ & 0.0250 & 0.0260 & 0.0125 & 0.0214 \\
$2,000 \mathrm{mg} / \mathrm{L}-30^{\circ} \mathrm{C}$ & 0.0245 & 0.0253 & 0.0125 & 0.0214 \\
$2,000 \mathrm{mg} / \mathrm{L}-35^{\circ} \mathrm{C}$ & 0.0245 & 0.0253 & 0.0125 & 0.0214 \\
$5,000 \mathrm{mg} / \mathrm{L}-25^{\circ} \mathrm{C}$ & 0.0263 & 0.0263 & 0.0173 & 0.0312 \\
$5,000 \mathrm{mg} / \mathrm{L}-30{ }^{\circ} \mathrm{C}$ & 0.0256 & 0.0257 & 0.0173 & 0.0312 \\
$5,000 \mathrm{mg} / \mathrm{L}-35^{\circ} \mathrm{C}$ & 0.0255 & 0.0255 & 0.0173 & 0.0312 \\
\hline
\end{tabular}

Table 11. Total average energy demand for each test.

\begin{tabular}{cccc}
\hline Arrangement & $\begin{array}{c}\mathbf{1 0 ~ V} \\
\mathbf{( k W h}\end{array}$ & $\begin{array}{c}\mathbf{2 0 ~ V} \\
\mathbf{( k W h}\end{array}$ & $\begin{array}{c}\text { Increased energy } \\
\text { consumption (\%) }\end{array}$ \\
\hline $2,000 \mathrm{mg} / \mathrm{L}-25{ }^{\circ} \mathrm{C}$ & 0.0375 & 0.0474 & 26.4 \\
$2,000 \mathrm{mg} / \mathrm{L}-30{ }^{\circ} \mathrm{C}$ & 0.037 & 0.0467 & 26.22 \\
$2,000 \mathrm{mg} / \mathrm{L}-35{ }^{\circ} \mathrm{C}$ & 0.037 & 0.0467 & 26.22 \\
$5,000 \mathrm{mg} / \mathrm{L}-25{ }^{\circ} \mathrm{C}$ & 0.0436 & 0.0575 & 31.88 \\
$5,000 \mathrm{mg} / \mathrm{L}-30{ }^{\circ} \mathrm{C}$ & 0.0429 & 0.0569 & 32.63 \\
$5,000 \mathrm{mg} / \mathrm{L}-35{ }^{\circ} \mathrm{C}$ & 0.0428 & 0.0567 & 32.48 \\
\hline
\end{tabular}

In all cases, the energy consumption or expenditure was higher in the tests in which $20 \mathrm{~V}$ was applied because the rectifier requires more energy to produce the power demand 
for the current; while with respect to the increase in temperature $\left(25-35^{\circ} \mathrm{C}\right)$ the energy consumed decreased because the viscosity of the brackish water also decreased, which means less opposition of the fluid to be transported by the pump equipment [26]. Tests at $5,000 \mathrm{mg} / \mathrm{L}$ in the feed were more energy demanding than those at lower concentrations because it required more energy to maintain the rectifiers at the set voltage, while the pumps also needed more energy.

\subsubsection{Water cost evaluation}

The costs of water production in desalination vary in a wide range; this depends on different factors, among which the following are mainly highlighted: the quality of the source water, the quality of the demanded water, the plant capacity, among others [27]. To estimate the energy cost of the process, the water quality demanded was set at 500 $\mathrm{mg} / \mathrm{L}$, a concentration that is below that required by NOM-127. For all cases, the time required to reach that concentration was estimated and projected for a 24-hour operation; the latter in order to compute the energy consumption spread over an entire day. Finally, the cost per cubic meter of water was obtained from the average basic consumption rate given by CFE [28].

Table 12 summarizes the energy costs of production per cubic meter of water for all arrangements.

Table 12. Energy cost per cubic meter of water.

\begin{tabular}{ccc}
\hline Arrangement & \multicolumn{2}{c}{$\begin{array}{c}\text { Production energy cost } \\
\text { (USD\$/m }\end{array}$} \\
& $\mathbf{1 0 ~ V ~}$ & $\mathbf{2 0 ~ V}$ \\
\hline $2,000 \mathrm{mg} / \mathrm{L}-25{ }^{\circ} \mathrm{C}$ & 0.52 & 0.66 \\
$2,000 \mathrm{mg} / \mathrm{L}-30{ }^{\circ} \mathrm{C}$ & 0.51 & 0.65 \\
$2,000 \mathrm{mg} / \mathrm{L}-35{ }^{\circ} \mathrm{C}$ & 0.51 & 0.65 \\
$5,000 \mathrm{mg} / \mathrm{L}-25{ }^{\circ} \mathrm{C}$ & 0.61 & 0.80 \\
$5,000 \mathrm{mg} / \mathrm{L}-30{ }^{\circ} \mathrm{C}$ & 0.60 & 0.79 \\
$5,000 \mathrm{mg} / \mathrm{L}-35^{\circ} \mathrm{C}$ & 0.59 & 0.78 \\
\hline
\end{tabular}

The above data show that the price increases if the feed stream is more concentrated. On the other hand, as expected, it is observed for tests of the same voltage that the cost decreases for the increase in temperature; the same trend is detectable at $20 \mathrm{~V}$. Lower voltage operations are cheaper than their counterpart, however, less cubic meters are desalinated. The price range of product water in desalination processes is reported to be between 0.48 and $3.59 \mathrm{USD} \$ / \mathrm{m}^{3}$ [29]. The production is also below the prices of electrodialysis in recent years $\left(0.75 \mathrm{USD} \$ / \mathrm{m}^{3}\right)$ [30]. In addition, Dévora et al. [27] report that the price of reverse osmosis water is around $0.6 \mathrm{USD} \$ / \mathrm{m}^{3}$.

\section{Conclusions}

It is concluded that the increase in temperature and voltage are parameters that positively affect the salt removal efficiency of the EDR process. It was found that a voltage of $20 \mathrm{~V}$ and $35^{\circ} \mathrm{C}$ have the best combination of operating parameters to have the highest salt removal at $89.5 \%$ and $94.24 \%$ for salinities of 5,000 and 2,000 mg/L, respectively. The time to reach the concentration suitable for human consumption of $500 \mathrm{mg} / \mathrm{L}$ according to NOM-127 in the $5,000 \mathrm{mg} / \mathrm{L}$ concentration test at $20 \mathrm{~V}$ and $35^{\circ} \mathrm{C}$ was $13 \mathrm{~min}$, while in the $2,000 \mathrm{mg} / \mathrm{L}$ test at $20 \mathrm{~V}$ and $35^{\circ} \mathrm{C}$ it was $7 \mathrm{~min}$.

Energy consumption was reduced throughout the process with increasing temperature, $1.33 \%$ and $1.47 \%$ for the 2,000 and $5,000 \mathrm{mg} / \mathrm{L}$ TDS arrays at $10 \mathrm{~V}$; while the savings at $20 \mathrm{~V}$ were $1.83 \%$ and $1.39 \%$ at 2,000 and $5,000 \mathrm{mg} / \mathrm{L}$ TDS respectively. All the energy savings had an impact on the cost of production to make it more economical, the price range per $\mathrm{m}^{3}$ is between $\$ 0.52$ and $\$ 0.78$. The present study demonstrates the importance of desalination by membrane systems and temperature application, since the economic 
feasibility and time optimization make it profitable. It also represents an alternative solution for scaling up EDR processes for coastal communities that do not have water and energy, by providing sustaining water.

Author Contributions: G.E.D.I. helped revising the paper. A.A.E. conducted the experiments and wrote the results discussion. L.A.L.R. helped writing the results discussion and edited the paper.

Funding: This research was funded through the Research Promotion and Support Program with registration code: PROFAPI_2020_0009. Technological Institute of Sonora.

Institutional Review Board Statement: Not applicable.

Data Availability Statement: The data presented in this study are available on request from the corresponding author.

Acknowledgments: L.A.L.R. helped translate and edited the paper

Conflicts of Interest: The authors declare no conflicts of interest.

\section{References}

[1] S. J. Marshall, "Hydrology," in Reference Module in Earth Systems and Environmental Sciences, Elsevier, 2013.

[2] F. R. Rijsberman, "Water scarcity: Fact or fiction?," Agric. Water Manag., vol. 80, no. 1-3, pp. 5-22, Feb. 2006, doi: 10.1016/j.agwat.2005.07.001.

[3] CONAGUA, “Estadísticas del Agua en México, Edición 2017,” 2017.

[4] M. R. Medina, R. M. Saavedra, M. M. Montaño, and J. C. Gurrola, “Vulnerabilidad a la intrusión marina de acuíferos costeros en el Pacífico Norte Mexicano; un caso, el acuífero costa de Hermosillo, Sonora, México," Rev. Latino-Americana Hidrogeol., vol. 2, pp. 31-51, 2002, doi: 10.5380/hg.v2i0.2620.

[5] G. E. Dévora-Isiordia, M. E. López-Mercado, G. A. Fimbres-Weihs, J. Álvarez-Sánchez, and S. Astorga-Trejo, “Desalación por ósmosis inversa y su aprovechamiento en agricultura en el valle del Yaqui, Sonora, México," Tecnol. y Ciencias del Agua, vol. 7, no. 3, pp. 155-169, 2016.

[6] R. Monreal, J. Castillo, M. Rangel, M. Morales, L. A. Oroz, and H. Valenzuela, “La intrusión salina en el acuífero de la Costa de Hermosillo, Sonora," in Acta de Sesiones de la XXIV Convención Internacional de la Asociación de Ingenieros de Minas Metalurgistas y Geólogos de México A.C., Acapulco Guerrero, 17-20 de octubre del 2001, 2001, pp. 93-98.

[7] W. S. Gillam and W. H. McCoy, “Desalination Research and Water Resources," in Principles of Desalination, Elsevier, 1966, pp. $1-20$.

[8] A. Robles-Lizárraga, M. del R. Martínez-Macías, M. I. Encinas-Guzmán, O. de J. Larraguibel-Aganza, J. Rodríguez-López, and G. E. Dévora-Isiordia, “Design of reverse osmosis desalination plant in Puerto Peñasco, Sonora, México," Desalin. water Treat., vol. 175, pp. 1-10, 2020, doi: 10.5004/dwt.2020.24739.

[9] V. Belessiotis, S. Kalogirou, and E. Delyannis, "Desalination Methods and Technologies - Water and Energy," in Thermal Solar Desalination, Elsevier, 2016, pp. 1-19.

[10] G. Ruan, M. Wang, Z. An, G. Xu, Y. Ge, and H. Zhao, "Progress and Perspectives of Desalination in China," Membranes (Basel)., vol. 11, no. 3, p. 206, Mar. 2021, doi: 10.3390/membranes11030206.

[11] H. Strathmann, "Chapter 1 Overview of Ion-Exchange Membrane Processes," in Membrane Science and Technology, vol. 9, no. C, H. Strathmann, Ed. Elsevier, 2004, pp. 1-22.

[12] H. Strathmann, "Assessment of Electrodialysis Water Desalination Process Costs," Proc. Int. Conf. Desalin. Costing, Lemassol, Cyprus, December 6-8, 2004, no. January, pp. 32-54, 2004.

[13] W. E. Katz, “The electrodialysis reversal (EDR) process," Desalination, vol. 28, no. 1, pp. 31-40, Jan. 1979, doi: 10.1016/S00119164(00)88124-2.

[14] G. E. Dévora-Isiordia and R. Gonzalez-Enriquez, "Técnicas para desalinizar agua de mar y su desarrollo en México," Ra Ximhai, vol. 8(2), pp. 47-54, May 2012, doi: 10.35197/rx.08.02.e.2012.05.gd. 
[15] Y. Tanaka, "A computer simulation of continuous ion exchange membrane electrodialysis for desalination of saline water," Desalination, vol. 249, no. 2, pp. 809-821, Dec. 2009, doi: 10.1016/j.desal.2009.04.011.

[16] G. E. Dévora-Isiordia, A. Robles-Lizárraga, L. A. Lares-Rangel, J. C. Valdez-Valdez, and I. Y. Torres-Valenzuela, “Desalación de aguas salobres por Electrodiálisis Reversible: Viabilidad para rescate de pozos abandonados en Sonora, México," Rev. Latinoam. Recur. Nat., vol. 15, no. 3, pp. 77-87, 2019.

[17] S. Honarparvar, X. Zhang, T. Chen, A. Alborzi, K. Afroz, and D. Reible, “Frontiers of Membrane Desalination Processes for Brackish Water Treatment: A Review," Membranes (Basel)., vol. 11, no. 4, p. 246, Mar. 2021, doi: 10.3390/membranes11040246.

[18] H. Strathmann, “Chapter 2 Electrochemical and thermodynamic fundamentals," in Membrane Science and Technology, vol. 9, no. C, H. Strathmann, Ed. Elsevier, 2004, pp. 23-88.

[19] A. M. Benneker, J. Klomp, R. G. H. Lammertink, and J. A. Wood, “Influence of temperature gradients on mono- and divalent ion transport in electrodialysis at limiting currents," Desalination, vol. 443, pp. 62-69, Oct. 2018, doi: 10.1016/j.desal.2018.05.005.

[20] K. Onuki, "Electro-electrodialysis of hydriodic acid in the presence of iodine at elevated temperature," J. Memb. Sci., vol. 192, no. 1-2, pp. 193-199, Oct. 2001, doi: 10.1016/S0376-7388(01)00500-2.

[21] J. Kucera, "Basic Terms and Definitions," in Reverse Osmosis, Hoboken, NJ, USA: John Wiley \& Sons, Inc., 2015, pp. 25-48.

[22] R. Singh, "Desalination and On-site Energy for Groundwater Treatment in Developing Countries Using Fuel Cells," in Emerging Membrane Technology for Sustainable Water Treatment, Elsevier, 2016, pp. 135-162.

[23] C.-V. Gherasim, J. Křivčík, and P. Mikulášek, "Investigation of batch electrodialysis process for removal of lead ions from aqueous solutions," Chem. Eng. J., vol. 256, pp. 324-334, Nov. 2014, doi: 10.1016/j.cej.2014.06.094.

[24] N. Kabay, Ö. Arar, S. Samatya, Ü. Yüksel, and M. Yüksel, “Separation of fluoride from aqueous solution by electrodialysis: Effect of process parameters and other ionic species," J. Hazard. Mater., vol. 153, no. 1-2, pp. 107-113, May 2008, doi: 10.1016/j.jhazmat.2007.08.024.

[25] “NOM-127-SSA1-1994, 'Salud ambiental. Agua para uso y consumo humano. Límites permisibles de calidad y tratamientos a que debe someterse el agua para su potabilización,'” 2000.

[26] F. B. Leitz, M. A. Accomazzo, and W. A. McRae, “High temperature electrodialysis,” Desalination, vol. 14, no. 1, pp. 33-41, Feb. 1974, doi: 10.1016/S0011-9164(00)80045-4.

[27] G. E. Dévora-Isiordia, R. González-Enríquez, and S. Ruiz-Cruz, “Evaluación de procesos de desalinización y su desarrollo en México," Tecnología y ciencias del agua, vol. 4. scielomx, pp. 27-46, 2013.

[28] CFE, “Tarifas.” [Online]. Available: https://app.cfe.mx/Aplicaciones/CCFE/Tarifas/Tarifas/tarifas_casa.asp. [Accessed: 15Apr-2021].

[29] I. C. Karagiannis and P. G. Soldatos, “Water desalination cost literature: review and assessment," Desalination, vol. 223, no. 1-3, pp. 448-456, Mar. 2008, doi: 10.1016/j.desal.2007.02.071.

[30] S. Al-Amshawee, M. Y. B. M. Yunus, A. A. M. Azoddein, D. G. Hassell, I. H. Dakhil, and H. A. Hasan, “Electrodialysis desalination for water and wastewater: A review," Chem. Eng. J., vol. 380, p. 122231, Jan. 2020, doi: 10.1016/j.cej.2019.122231. 